\title{
AUTONOMIC SEIZURES AND AUTONOMIC STATUS EPILEPTICUS IN EARLY ONSET BENIGN CHILDHOOD OCCIPITAL EPILEPSY
}

\section{Panayiotopoulos syndrome}

\author{
Gloria Maria Almeida Souza Tedrus' ${ }^{1}$ Lineu Corrêa Fonseca ${ }^{1}$
}

\begin{abstract}
To study clinical and EEG features of children with ictal vomiting and no underlying brain lesions (Panayiotopoulos syndrome). The subjects were 36 children aged 2-13 years. The onset of seizures occurred between 1 and 5 years of age. Fourteen children (38.8\%) had a single seizure. Fourteen children $(38.8 \%)$ had autonomic status epilepticus. Impairment of consciousness was reported in $30(83.3 \%)$ children, eye deviation in $10(27.7 \%)$ other autonomic symptoms and head deviation in 9 , generalization in 8 , visual symptoms in one child, and, speech arrest or hemifacial motor symptoms in 8 cases. The EEG showed occipital spikes or spike-wave complexes in $27(75.0 \%)$ children, blocked by opening of the eyes in $8(22.2 \%)$ cases. Nine patients $(25 \%)$ also had rolandic spikes and 3 had extraoccipital spikes. Six (16.6\%) patients had normal EEG. No clinical differences were observed between patients having occipital or extraoccipital spikes. In children only with autonomic seizures, the spikes are predominantly occipital but blockage by opening of the eyes is a less frequent feature. In some children there is an overlapping of different focal childhood idiopathic syndromes.
\end{abstract}

KEY WORDS: benign childhood epilepsy, eletroencephalography, epileptiform activity, ictus emeticus, occipital spikes, Panayiotopoulos syndrome.

\begin{abstract}
Crises autonômicas e status epilepticus autonômico na epilepsia occipital benigna da infância de início precoce (síndrome de Panayiotopoulos)

RESUMO - Estudar aspectos clínico-eletrencefalográficos de crianças com vômito ictal e sem sinais de lesão cerebral (síndrome de Panayiotopoulos). Foram estudadas 36 crianças na faixa etária de 2-13 anos. O início das crises ocorreu entre 1 e 5 anos de idade. Quatorze crianças tiveram crise única. Status epilepticus foi observado em $14(38,8 \%)$ casos. Distúrbio da consciência foi relatado em 83,3\% das crianças, desvio ocular em $27,7 \%$, outros sintomas autonômicos e desvio da cabeça em $26,4 \%$, generalização em $23,5 \%$, bloqueio da fala ou sintomas motores da hemiface em $23,5 \%$ das crianças e sintomas visuais em um caso. O EEG mostrou pontas ou complexos de ponta-onda em $27(75,0 \%)$ casos, bloqueados pela abertura dos olhos em $8(22,2 \%)$ pacientes. Nove pacientes tiveram também pontas rolândicas e 3, pontas extraoccipitais outras. O EEG foi normal em 6 crianças. Não houve diferença clínica entre as crianças com pontas occipitais e extraoccipitais. Em crianças com crises autonômicas as pontas foram de predomínio occipital, mas bloqueio pela abertura dos olhos foi pouco freqüente. Em alguns casos houve sobreposição de diferentes síndromes idiopáticas focais da infância.
\end{abstract}

PALAVRAS-CHAVE: epilepsia benigna da infância, eletrencefalografia, atividade epileptiforme, ictus emeticus, espículas occipitais, síndrome de Panayiatopoulos.

Panayiotopoulos (1988) ${ }^{1}$ described a form of childhood benign focal epilepsy corresponding to about $6 \%$ of the epilepsies occurring in this age range, with an incidence peak at 5 years of age and affecting both sexes equally. The prognostic is good and seizure remission frequently occurs within 1 or 2 years of the onset. The crises are focal, initially characterised by a complaint from the child of "not feeling well", followed by autonomic signs or symptoms frequently characterised by nausea or vomiting. During the seizure evolution, the child becomes flaccid and unresponsive, with a tonic eye and/or head deviation, and,

'Professor of Neurology. School of Medicine, Pontifícia Universidade Católica de Campinas, Campinas SP, Brazil.

Received 16 January 2006, received in final form 18 April 2006. Accepted 8 June 2006.

Dra. Gloria Tedrus - Rua Sebastião de Souza 205 / 122 - 13013-173 Campinas SP - Brasil. E-mail: gmtedrus@uol.com.br 
in some cases, followed by a generalised convulsion or motor hemiconvulsion. The seizures are frequently prolonged and in one third of the cases there is just one single seizure. In approximately $60 \%$ of the children, the seizures occur while sleeping. Some of the children present other autonomic manifestations such as: paleness, cyanosis, pupil dilation, facial blushing, coughing, urinary and/or faecal incontinence and even irregular breathing. The background activity (BA) of the electroencephalogram (EEG) is normal and in $90 \%$ of the cases, the epileptiform activity (EA) is characterised by spikes or spike-wave complexes of great amplitude and a functional nature, with multifocal localisation predominating in the posterior regions. Occipital localisation of the EA occurs in approximately $68 \%$ of the children. The EA frequently disappears at about thirteen years of age but may persist after remission of the clinical seizures ${ }^{1,2}$.

Recently this form of epilepsy was recognised as early-onset benign occipital childhood epilepsy (EOOE) in the proposal of the Task Force on Classification and Terminology of the International League Against Epilepsy (ILAE) ${ }^{3}$. However, several publications question the classification of this epileptic syndrome as occipital epilepsy, since the commonest ictal characteristics suggest an extra-occipital location and the EEG alterations are frequently multifocal, despite the elevated occurrence of occipital-located spikes ${ }^{2,4-6}$. Since autonomic expressions are frequent amongst the critical manifestations of EOOE, various recent studies have specifically approached this clinical aspect ${ }^{6-8}$.

Thus the objectives of the present research were to study the correlation between the electroencephalographic characteristics and the clinical aspects of children with autonomic focal seizures with Panayiotopoulos syndrome.

\section{METHOD}

In a retrospective way, the medical registers of children examined in the Electroencephalographic Service of the Celso Pierro General \& Maternity Hospital (PUC-Campinas) and in the private clinics of the authors, presenting focal epileptic seizures starting with nausea and/or vomiting followed by other critical autonomic symptomatology or even that of a generalised secondary nature with diagnosis of early onset benign childhood occipital epilepsy (Panayiotopoulos syndrome), were analysed.

The inclusion criteria were: critical autonomic symptomatology, normal neurological examination, normal neuropsychomotor development, no past history suggestive of neurological disorders, normal computerized tomography (CT) scan, and normal intercritical EEG background activity?

The age and gender of the children were noted from the registers and the type, total number and duration of the seizures and the age when they occurred, noted and analysed.

From the EEG the following were studied: presence of EA according to type - spikes (S) or spike-wave complexes (SWC) -, location, extension and reactivity to the opening and closing of the eyes. The presence of spikes evoked (ES) by hand and foot stimulation was also studied.

The research plan was approved by the Ethics Commission for Research in Human Beings of PUC-Campinas.

\section{RESULTS}

Thirty-six children presenting autonomic epileptic seizures were included in this study. The initial manifestation was nausea and/or vomiting in all the cases. Other autonomic manifestations (paleness, abdominal pain and cyanosis) were observed in $50 \%$ of the cases.

During the sequence of the seizures, eye deviation occurred in $10(27.7 \%)$ cases and head deviation in $9(25 \%)$. Complaints about vision were made in one case and $8(22.2 \%)$ had seizures with speech arrest or hemifacial motor symptoms, choking sensation or parestesias of the hands. Impairment of consciousness was noted during the seizure in 30 (83.3\%) of the children, hemiconvulsions in $5(13.8 \%)$ cases, generalised convulsions in $3(8.3 \%)$ and postictal symptoms were referred to in $11(30.5 \%)$ children.

The seizures occurred while sleeping in 26 (72.2\%) cases.

The seizures started between 1 and 5 years of age in $86.1 \%$ of the cases (average age 4 years). The female gender showed a discreet, non-significant predomination (58.3\%). In $80 \%$ of the children the total number of seizures was up to 3 episodes, 14 children only had one single seizure and seizures were numerous in 7 children. In 14 children (38.8\%), the seizures lasted more than 20 minutes, characterising autonomic status epilepticus.

Electroencephalographic aspects - As the inclusion criteria all the children showed normal BA in the EEG.

Thirty children (83.3\%) presented EA.

The EA was occipital-located in $27(75 \%)$ of the children. It was exclusively occipital in 18 cases but there was also generalised SWC in 3 cases and extraoccipital (central and mid-temporal) in 9 children. In 8 cases, on opening the eyes, blocking or attenuation of the occipital EA occurred.

Three children presented EA in the central and mid-temporal regions and in 6 cases there was no register of EA on the EEG.

ES was found in 1 case $(2.7 \%)$ due to stimulation of the feet and hands. 
Table. Clinical characteristics of the children with autonomic seizures according to the EEG findings.

\begin{tabular}{|c|c|c|c|c|c|c|c|c|c|c|c|c|}
\hline \multirow[t]{2}{*}{ Electroencephalogram } & \multicolumn{3}{|c|}{ Total $n^{\circ}$ of seizures } & \multicolumn{9}{|c|}{ Critical characteristics } \\
\hline & 1 & $2-3$ & $>10$ & dev. & $\begin{array}{l}\text { imp. } \\
\text { con. }\end{array}$ & mot & $\begin{array}{l}\text { oro- } \\
\text { phar }\end{array}$ & vis & gen & sleep & $\begin{array}{l}\text { post- } \\
\text { ictal }\end{array}$ & status \\
\hline Normal $n=6$ & 4 & - & 2 & 3 & 5 & 2 & - & 1 & - & 3 & 3 & 2 \\
\hline EA occ. $n=18$ & 8 & 7 & 3 & 8 & 13 & 3 & 5 & - & 2 & 16 & 6 & 9 \\
\hline $\begin{array}{l}\text { EA occ. \& centro- } \\
\text { temporal } n=9\end{array}$ & - & 8 & 1 & 3 & 9 & 1 & 2 & - & 1 & 5 & 2 & 3 \\
\hline EA centro-temporal $n=3$ & 2 & - & 1 & 2 & 3 & 1 & 1 & - & - & 2 & - & - \\
\hline Total & 14 & 15 & 7 & 16 & 30 & 7 & 8 & 1 & 3 & 26 & 11 & 14 \\
\hline
\end{tabular}

n, number of cases; occ, occipital; $n^{\circ}$, number; dev., eye and/or head deviation; imp. com., impairment of consciousness; mot, focal or hemigeneralised motor seizure; oro-phar, oro-pharyngeal manifestation; vis, focal with visual symptoms; gen, seizure followed by tonic-clonic generalisation; sleep, seizure while sleeping; status, seizures lasting $>20$ minutes.

No significant differences were observed between the clinical and critical aspects amongst the children with occipital or extra-occipital EA or with normal EEG (Table).

\section{DISCUSSION}

The findings of this study with respect to the age of the child and the number, duration and characteristics of the seizures, corroborated the data found in previous publications involving approximately 800 cases of EOOE described in the literature ${ }^{1,4,5,9-11}$.

As already mentioned ${ }^{2,4,9-12}$ some cases $(22.2 \%)$ were observed involving only a single seizure, in which the autonomic symptomatology was followed by oro-pharyngeal manifestation, characteristics suggesting the overlapping of two benign childhood epilepsies, the early onset occipital one and that with centro-temporal spikes.

With respect to $E A$, the predominant region was occipital in the majority of cases, exclusively centrotemporal in some and inexistent in others. In a significant way, differences were not observed between the children presenting occipital or centro-temporal focal EA or normal EEG with respect to the total number of seizures, the duration or the type of seizure. These findings are consistent with the initial description of Panayiotopoulos and that of other authors ${ }^{1,2,5,9}$.

In $37 \%$ of the cases, the occipital EA was characterised by spikes, a finding similar to that of other authors, who also suggested similarity between the neurophysiological characteristics of this occipital EA with those of the rolandic spikes of BIECT ${ }^{1,2,9}$. In $29.6 \%$ of the cases, blockage or attenuation of the occipital EA was caused by opening the eyes, a lower per- centage than the $80 \%$ and $100 \%$ of cases reported respectively by Caraballo et al. ${ }^{9}$ and Verroti et al. ${ }^{13}$, but similar to that reported by other authors ${ }^{5,14}$.

In the children presenting occipital EA, $11.1 \%$ of the cases were observed to present generalised SWC, in agreement with other studies ${ }^{2,9}$.

Analogous to the study of Covanis et al. ${ }^{8}$, some of the children with autonomic clinical manifestations presented exclusively centro-temporal EA in the EEG.

ES by foot stimulation was observed in one (2.7\%) child. In previous studies ${ }^{15}$ it had already been observed that ES could appear on the EEG due to several types of epileptic syndrome, particularly with benign focal epilepsy in childhood, but that it could also appear in normal children with no epileptic manifestations ${ }^{16}$.

In conclusion, in the children studied a focal epileptic state is relatively frequent. The EEG showed that the EA was preferentially occipital, consisting of spikes and/or SWC that could, in some cases, be blocked by opening the eyes. Centro-temporal EA occurred in a significant percentage of the cases and could be the only alteration seen on the EEG. There was overlapping of the clinical and electroencephalographic characteristics in some cases, suggestive of two benign childhood epileptic syndromes, the early onset occipital one and that with centro-temporal spikes.

\section{REFERENCES}

1. Panayiotopoulos CP. Vomiting as an ictal manifestation of epileptic seizures and syndromes. J Neurol Neurosurg Psychiatry 1988;51:14481451.

2. Panayiotopoulos CP. Panayiotopoulos syndrome: a common and benign childhood epileptic syndrome. London: John Libbey Company, 2002.

3. Engel J. A proposed diagnostic scheme for people with epileptic seizures and with epilepsy: report of the ILAE task force on classification and terminology. Epilepsia 2001;42:1-6. 
4. Ferrie CD, Beaumanoir A, Guerrini R. Early-onset benign occipital seizure susceptibility syndrome. Epilepsia 1997;38:285-293.

5. Lada C, Skiadas K, Theodorou V, Loli N, Covanis A. A study of 43 patients with Panayiotopoulos syndrome, common and benign childhood seizure susceptibility. Epilepsia 2003;44:81-88.

6. Panayiotopoulos CP. Autonomic seizures and autonomic status epilepticus specific to childhood. Arch Pediatr Adolesc Med 2002;156:945.

7. Panayiotopoulos CP. Autonomic seizures and autonomic status epilepticus peculiar to childhood: diagnosis and management. Epilepsy Behav 2004;5:286-295.

8. Covanis A, Lada C, Skiadas K. Children with rolandic spikes and ictal vomiting: rolandic epilepsy or Panayiotopoulos syndrome? Epileptic Disord 2003;5:139-143.

9. Caraballo R, Cersosimo R, Medina C, Fejerman N. Panayiotopoulostype benign childhood occipital epilepsy: a prospective study. Neurology 2000;55:1096-1100.

10. Kivity S, Ephraim T, Weitz R, Tamir A. Childhood epilepsy with occipital paroxysms: clinical variants in 134 patients. Epilepsia 2000;41:15221533.
11. Fonseca LC, Tedrus GMA. Epilepsia occipital benigna da infância de início precoce (tipo Panayiotopoulos): aspectos clínicos e eletrencefalográficos evolutivos em 14 crianças. Arq Neuropsiquiatr 2005;63:464469.

12. Tedrus GMA, Fonseca LC. Epilepsias idiopáticas focais occipitais da infância: estudo de 63 casos. Arq Neuropsiquiatr 2005;63:61-67.

13. Verroti A, Domizio S, Guerra M. Childhood epilepsy with occipital paroxysms and benign nocturnal childhood occipital epilepsy. J Child Neurol 2000;15:219-221.

14. Vigevano F, Ricci S. Benign occipital epilepsy of childhood with prolonged seizures and autonomic symptoms. In: Andermann $\mathrm{F}$, Beaumanoir A, Mira L, Roger J, Tassinari CA (eds). Occipital seizures and epilepsies in children. London: John Libbey, 1993:133-140.

15. Fonseca LC, Tedrus GMA. Epileptic syndromes in children with somatosensory evoked spikes. Clin Electroenceph 1994;25:54-58.

16. Fonseca LC, Tedrus GMA. Pontas evocadas por estímulos somatossensitivos e atividade epileptiforme no eletrencefalograma em crianças normais. Arq Neuropsiquiatr 2003;61:793-795. 